\title{
EFFECT OF MANIPULATED SEX RATIO ON INSEMINATION OF THE RED MASON BEE OSMIA BICORNISL. UNDER NET CAGE CONDITIONS
}

\author{
Monika Fliszkiewicz* \\ Aleksandra Langowska \\ Piotr Tryjanowski \\ Institute of Zoology, Poznań University of Life Sciences, Wojska Polskiego \\ 71C, 60-625 Poznań, Poland \\ *corresponding author: monef@up.poznan.pl \\ Received 15 November 2012; accepted 10 October 2013
}

A bstract

The red mason bee Osmia bicornis L. (Hymenoptera: Megachilidae) is a solitary gregarious species that is known to be a good pollinator of pear, apple, and several other Rosaceae fruit plants. Mainly females are active in plant pollination, and therefore they are of strong interest to farmers. As natural populations are usually male biased, here we studied the possibility of rearing a female-biased population of Osmia bicornis by examining the effects of sex ratio changes on female survival, insemination rate, and sperm count in the spermatheca. Using bees that had completed their winter diapause and were maintained in flying cages, we created three groups with different male:female sex ratios: 1:1, 1:2, and 1:3. The 1:3 sex-ratio group exhibited the best survival of females, but the lowest spermathecae sperm count. The insemination rate did not differ between groups. Our results indicate that-at least among bees housed in isolator cages for plant breedingskewing the sex ratio towards more females does not affect bee survival, and efficient insemination can be expected with twice as many females as males.

Keywords: Megachilidae, Osmia bicornis, sex ratio, spermatheca, sperm.

\section{INTRODUCTION}

In recent years, a worldwide decrease in the number of pollinators has been observed (Kearns et al., 1998). Although more attention has been paid to the honey bee Apis mellifera L., the economic importance of pollination services (Batra, 1995; Klein et al., 2007) has also raised interest in wild bee conservation and management (e.g. Kemp, 2000; Winfree et al. 2007). Studies have confirmed the importance of wild pollinators, including solitary wild bees, as good pollinators of both wild and crop plants (Batra, 1995; Delaplane and Mayer, 2000; Monzón et al., 2004; Garibaldi et al., 2013).

The red mason bee Osmia bicornis L. (Hymenoptera: Megachilidae) is one of the most abundant solitary bees in Central Europe (Westrich, 1989). It has only one generation per year and is a polylectic species that feeds on various flowers. Osmia bicornis inhabits hollow plant stems and natural or man-made holes in wood.
The species is a good pollinator of pear, apple, and several other rosaceous fruit plants (Delaplane and Mayer, 2000; Wilkaniec et al., 2002; Bosch and Kemp, 2002; Steffan-Dewenter, 2003). The red mason bee has a number of advantages over the honey bees and bumblebees (Bombus species) that are most commonly used for pollination. It is an effective pollinator in the field as well as in greenhouses, and has higher pollinating activity per bee, especially the females (e.g., Fliszkiewicz et al., 2011). It is a gentle species that causes no risk of stinging. Moreover, the red mason bee can be easily reared in artificial trap nests.

In a moderate climate, Osmia bicornis starts its activity in late March/early April. Over its lifetime, the female will build several line-type nests, comprising cells in linear order, separated by mud partitions. Daughter progeny can usually be found at the back of the nest, while sons are closer to the entrance (Seidelman et al., 2010). The adult females have an activity period of up 
to two months, and they die after completing their nests. The offspring in the nest undergo metamorphosis, during one stage of which the larva produces its cocoon. Metamorphosis is usually completed in September, and young adults remain in the nest sealed in the cocoon until the next spring

Adults that have not yet emerged from their cocoons can be cold stored $\left(4^{\circ} \mathrm{C}\right)$, such that in moderate climates they are available for pollination applications any time from March to September (unpublished results of M. Fliszkiewicz and personal communication with Giejdasz). Mainly the females are active in plant pollination (Delaplane and Mayer, 2000; Fliszkiewicz et al., 2011) and therefore they are of strong interest to farmers. In natural red mason bee populations, the sex ratio is rather skewed to males (Krunić and Stanisavljević, 2006), but the sex ratio can be manipulated by the size of an artificial nest (Wójtowski, 1971; Raw, 1972; Klostermeyer et al., 1973; Kristjansson, 1992; Wilkaniec et al., 2000; Budriené et al., 2004) and by improving the condition and size of the female bee (Seidelmann et al., 2010).

The pollinating advantage of female over male red mason bees, and the fact that it is quite easy to determine the sex of the bee at the adult cocoon stage, raises questions about the possibility of breeding populations with a modified sex ratio. In this short communication, we report on the reproductive potential - defined as insemination rate and sperm count in the spermathecae - of female-biased isolated groups of Osmia bicornis bees.

\section{MATERIAL AND METHODS}

\section{Bees and experimental design}

Red mason bees ( 0 . bicornis) were obtained from a population nesting in trap nests constructed with stalks of the common reed Phragmites australis, at an experimental station of the Department of Apidology, Institute of Zoology, Poznań University of Life Sciences, Poznań, Poland. Cocoons with adults were removed from nests and stored over the winter at $4^{\circ} \mathrm{C}$. After the winter diapause - in early April, which coincides with the natural appearance of the bee in Poland - the cocoons were carefully cut with scissors to enforce bee emergence. Simultaneous emerging prevented uncontrolled mating of bees before sexing and assignment to treatment groups. Sexing was performed based on the clypeus hair, among other observations. Randomly chosen bees were assigned to three experimental groups with different male:female sex ratios (real numbers in parentheses): 1:1 (30:30), 1:2 (15:30), and 1:3 (10:30). Bees were settled into cylindrical mesh plastic flying cages (100-cm diameter, $120-\mathrm{cm}$ height) with geotextile on the ground surface. Three cages were used per treatment, and thus we used a total of 270 females and 165 males. Cages were kept in the laboratory at $23^{\circ} \mathrm{C}$, with a light cycle of $12 \mathrm{~h}$ light: $12 \mathrm{~h}$ dark. Bees were given ad libitum sucrose solution (1:1 w:w) served in a Petri dish covered with a piece of bee wax foundation to prevent the bees from drowning. Cages were also supplied with fresh flowers of Tamarix parviflora, Prunus padus, Sambucus nigra, Robinia pseudoacacia, Prunus cerasifera, Malus domestica, Pyrus communis, Cerasus vulgaris, Prunus avium, Brassica napus, Aesculus hippocastanum, and Crataegus sp. Every two days, the syrup and flowers were exchanged, and dead individuals removed. Dead females were investigated for sperm presence in their spermathecae. After 14 days, the surviving females were killed with ethyl acetate and were dissected to check for sperm presence.

\section{Sperm counting}

Spermathecae were dissected under stereomicroscope. Every single spermatheca was placed in a drop of $0.9 \% \mathrm{NaCl}$ solution on a watch glass and gently crushed. The contents were thoroughly mixed with saline solution to $50 \mu \mathrm{L}$, and diluted with distilled water to a final volume of $200 \mu \mathrm{L}$. Distilled water kills sperm, which facilitated the counting of immobilized cells. A drop of the solution was placed on a FuchsRosenthal hemocytometer and examined using a phase-contrast microscope (20 × 10 magnification). The sperm count from five large squares of the hemocytometer ( $2 \mu \mathrm{L}$ solution) was used to calculate the total sperm number in the spermatheca (Woyke and Jasiński, 1973). 


\section{Statistical analysis}

Treatment groups were compared to evaluate the effects of sex ratio on female mortality (the number of females that died over the 14-day experiment), insemination success (the number of females with sperm found in their spermathecae), and sperm count in the spermathecae. Between-group differences in mortality rate and insemination success were compared using the $\chi^{2}$-test. A potential effect of sex ratio on sperm count in the spermathecae was investigated with a one-way ANOVA. The significance of differences between means was evaluated using Duncan's test, at a significance level of $\alpha=0.05$. All statistical operations were performed using Statgraphics Plus, v. 4.1.

\section{RESULTS}

\section{Survival pattern}

The three treatment groups differed significantIy in the proportion of dead females during the experiment $\left(\chi^{2}=6.30 ; P=0.044\right)$. The lowest mortality was observed in the 1:3 sex-ratio group, while the mortality rates in the $1: 2$ and 1:1 sex-ratio groups were higher and similar to each other (Fig. 1).

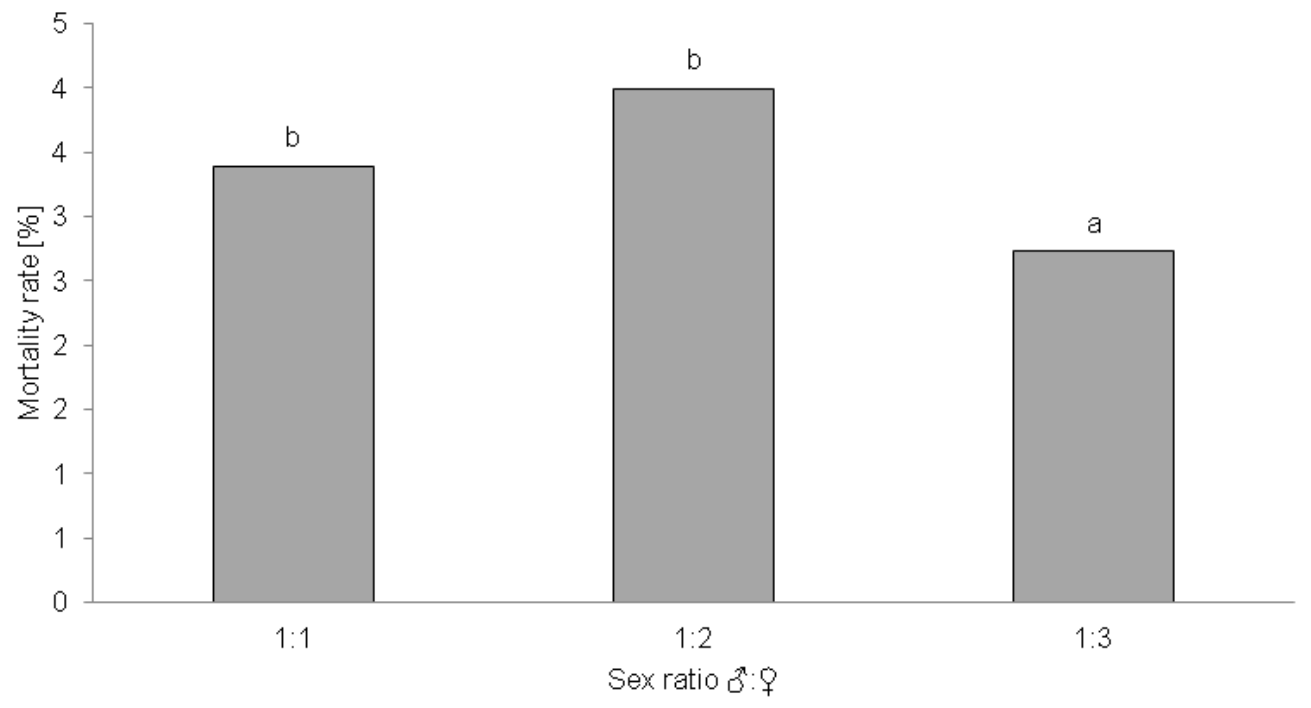

Fig. 1. Mortality rate (i.e., the proportion of dead bees in each treatment) of female Osmia bicornis bees maintained in cages for 14 days in different sex-ratio groups. The different letters above the bars indicate statistical differences between treatments.

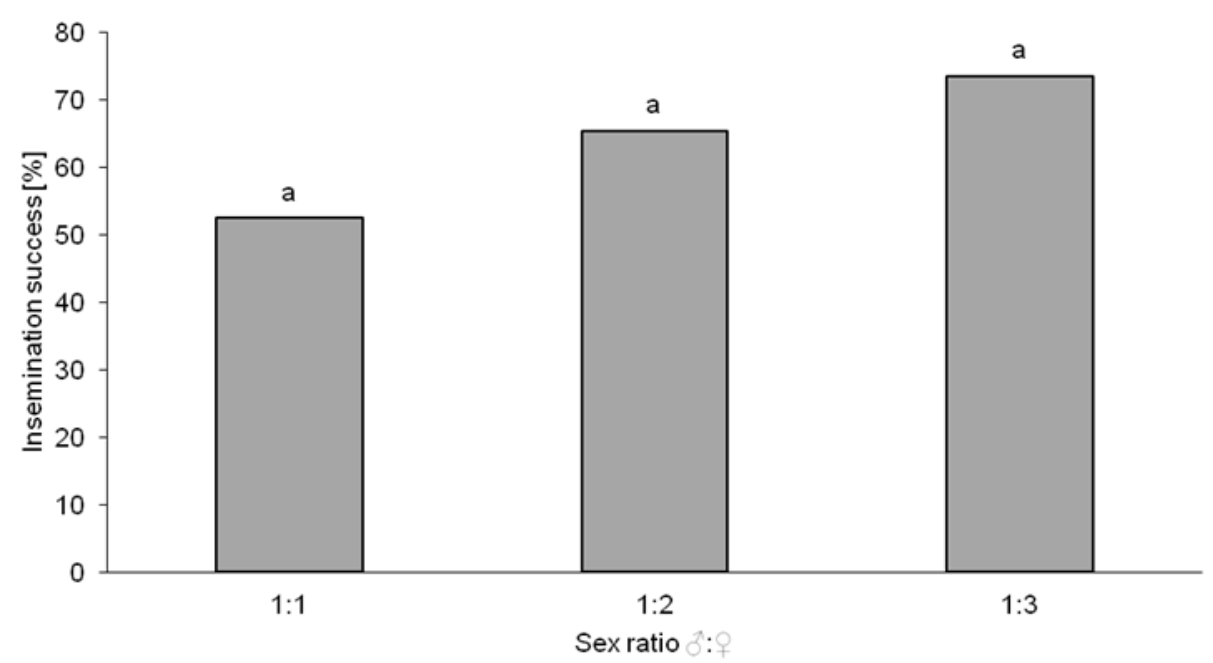

Fig. 2. Insemination success (i.e., the proportion of inseminated bees) of female Osmia bicornis bees maintained in cages in different sex-ratio groups. Different letters above the bars indicate statistical differences between treatments. 
Insemination success and sperm number Insemination success of female Osmia bicornis bees - defined as the percentage of inseminated females - ranged from $52.5 \%$ in the $1: 1$ treatment to $73.6 \%$ in the $1: 3$ treatment. However, this proportion did not significantly differ between the sex-ratio groups $\left(\chi^{2}=4.56\right.$, $\mathrm{P}=0.103$ ) (Fig. 2).

Sperm counts in the spermathecae of individuals from the $1: 2$ and 1:1 sex-ratio groups were statistically similar $\left(4.0 \times 10^{3}\right.$ and $3.4 \times 10^{3}$ sperm counted, respectively). Both were significantly higher than the sperm number found in the spermathecae of females from the 1:3 sex-ratio treatment group $\left(2.7 \times 10^{3}\right.$ sperm; $F_{2.6}=8.33$, $\mathrm{P}<0.001$ ) (Fig. 3). and 1:2 male:female ratio groups, supporting the possibility of manipulating the sex ratio of commercial Osmia bicornis stocks towards females, which are more efficient in pollination (Holm, 1973; Delaplane and Mayer, 2000) and thus more desired by farmers.

Although promising, our results do not provide a complete measure of the breeding success of the female-biased Osmia bicornis populations. In our experiment, we only measured the insemination rate; the nest-founding rate remains to be investigated. However, it is known that uninseminated females (in a population with a 0:1 male:female sex ratio) still found their nests with obvious male-only offspring production (Giejdasz, personal communication). We further

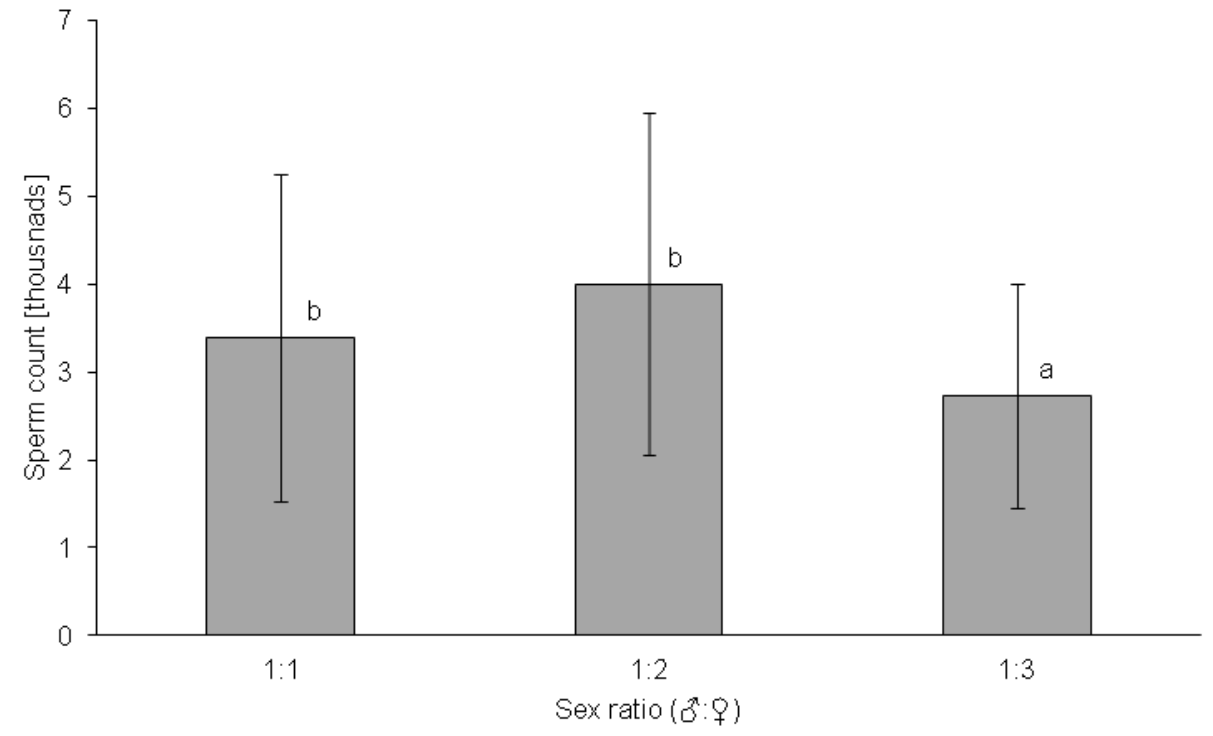

Fig. 3. Sperm number (in thousands; \pm standard deviation) in the spermathecae of female Osmia bicornis bees maintained in cages in different sex-ratio groups. Different letters above the bars indicate statistical differences between treatments.

\section{DISCUSSION}

0 . bicornis males can mate several times in their lifetime (Raw, 1976; Seidelmann, 1999; Fliszkiewicz and Wilkaniec, 2009), while females are monandrous (Seidelmann, 1999). This asymmetry provokes questions about whether successful insemination can be expected in populations with the sex ratio skewed to females. In our experiment, in a population with a ratio of one male to three females, the females received smaller portions of semen than in less femalebiased populations. However, sperm counts in the spermathecae were similar between the 1:1 observed relatively low mating and female survival rates, particularly in the 1:1 sex-ratio population. We believe this to be an artifact of the experimental conditions, i.e., increased bee density in a limited cage space. Due to the experimental set-up, the density of males was highest in the 1:1 sex-ratio group, which may have strongly affected social relations (Raw, 1976; Siedelmann, 1999). Strong competition for females between males might cause males to disturb female activities (Seidelmann, 1999), putting them into stressful conditions. Under natural conditions, these caging effects should not be observed. 
Manipulating the sex ratio of the stock toward females has advantages regarding its pollinating capability, but also has some potential pitfalls. Limiting the number of males available for copulation will decrease the genetic variation of the bee population. It may also promote males of a lower quality compared to the selection that occurs in natural sex-ratio populations. The sex ratio of managed Osmia bicornis populations can distinctly fluctuate between years, but Krunić and Stanisavljević (2006) reported that it was always male biased. Another important consideration relating to the use of a femalebiased population for breeding is that females must supply daughters with more food than sons (Ulbrich and Seidelmann, 2001; Bosch and Vicens, 2002; Strohm et al., 2002). Depending on their condition, the different costs of the sexes can lead to differential sex allocation by mothers (Alcock, 1979; Tepedino and Torchio, 1982; Strohm et al., 2002). Therefore, in addition to providing appropriate nesting material, e.g. reed stalks or nesting boards with holes of greater diameter (Raw, 1972; Tependino and Torhio, 1989; Kristjansson, 1992; Bosch and Vicens, 2002), it might become necessary to provide an additional supply of pollen to females (Klostermeyer et al., 1973; Seidelmann, 1999; Ulbrich and Seidelmann, 2001; Strohm et al., 2002; Bosch, 2008; Seidelmann et al., 2010). To address the growing needs of fruit farmers, further research is needed to determine the optimal conditions and limitations for rearing female-biased stocks of red mason bees.

\section{ACKNOWLEDGEMENTS}

The authors thank Dr. K. Giejdasz for helpful discussions.

\section{REFERENCES}

Alcock I. (1979) The relation between female body size and provisioning behavior in the bee Centris pallida Fox (Hymneoptera: Anthophoridae). Journal of the Kansas Entomological Society 52: 623-632.
Batra S. (1995) Bees and pollination in our changing environment. Apidologie 26: 361-370. DOl: 10.1051/apido:19950501

Bosch J. (2008) Production of undersized offspring in a solitary bee. Animal Behaviour 75: 809-816. Dol: 10.1016/j.anbehav.2007.06.018

Bosch J., Kemp W. P. (2002) Developing and establishing bee species as crop pollinators: the example of Osmia spp. (Hymenoptera: Megachilidae) and fruit trees. Bulletin of Entomological Research 92: 3-16. DOl: 10.1079/BER2001139

Bosch J., Vicens N. (2002) Body size as an estimator of production costs in a solitary bee. Ecological Entomology 27: 129-137. DOl: 10.1046/j.1365$2311.2002 .00406 . x$

Budriené A., Budrys E., Nevronyté A. (2004) Solitary Hymenoptera aculeate inhabiting trap-nests in Lithuania: nesting cavity choice and niche overlap. Latvijas Entomologos 41: 19-31.

Delaplane K. S., Mayer D. F. (2000) Crop pollination by bees. CABI Publishing Wallingford. UK. 344p.

Fliszkiewicz M., Wilkaniec Z. (2009) Potential possibilities of insemination of mason bee (Osmia bicornis L.) females by a single male in laboratory condition. Annals of Warsaw University of Life Sciences - SGGW Animal Science 46: 51-58.

Fliszkiewicz M., Giejdasz K., Wilkaniec Z. (2011) The importance of male red mason bee (Osmia bicornis L.) and male bufftailed bumblebee (Bombus terrestris L.) pollination in blackcurrant (Ribes nigrum L. Osmia bicornis L.). Journal of Horticultural Science and Biotechnology 86(5): 457-460.

Garibaldi L. A., Steffan-Dewenter I., Winfree R., Aizen M. A., Bommarco R., et al. (2013) Wild Pollinators Enhance Fruit Set of Crops Regardless of Honey Bee Abundance. Science 339(6127): 1608-1611. DOl: 10.1126/science. 1230200

Holm S. N. (1973) Osmia bicornis L. (Hym. Megachilidae) as pollinator of plants in greenhouses. Entomologica Scandinavica 4: 217-224. 
Kearns C. A., Inouye D. W., Waser N. M. (1998) Endangered mutualisms: the conservation of plantpollinator interaction. Annual Review of Ecology, Evolution, and Systematics 29: 83-1 12.

Kemp W. P. (2000) The future of crop pollination. American Bee Journal 140: 851-853.

Klein A. M., Vaissie B. E., Cane J. H., Steffan-Dewenter I., Cunningham S. A, Kremen C., Tscharntke T. (2007) Importance of pollinators in changing landscapes for world crops. Proceedings of the Royal Society $B$ 274: 303-313. DOl: 10.1098/rspb.2006.3721

Klostermeyer E., Mech S., Rasmussen W. (1973) Sex end weight of Megachile rotundata (Hymenoptera: Megachilidae) progeny associated with provision weights. Journal of the Kansas Entomological Society 46: 537-548.

Kristjansson K. (1992) Development of solitary bees as crop pollinators. In: Bees for pollination. Proceedings of an EC workshop. Brussels, Belgium. 2-3 March 1992. Commission of the European Communities. Division for the Coordination of Agricultural Research. pp. 91-109.

Krunić M., Stanisavljević L. (2006) Augmentation of managed populations of Osmia cornuta and Osmia bicornis (Hymenoptera: Megachilidae) in Southeastern Europe. European Journal of Entomology 103: 695-697.

Monzón V. H., Bosch J., Retana J. (2004) Foraging behavior and pollinating effectiveness of Osmia cornuta (Hymenoptera: Megachilidae) and Apis mellifera (Hymenoptera: Apidae) on "Comice" pear. Apidologie 35: 575-585. DOl: 10.1051/apido:2004055

Raw A. (1972) The biology of the solitary bee Osmia bicornis (L.) (Megachilidae). Trans. Proceedings of the Royal Entomological Society of London 124: 213-229.

Raw A. (1976) The behavior of males of the solitary bee Osmia bicornis (Megachilidae) searching for females. Behaviour 56: 279-285.
Seidelmann K. (1999) The Race for Females: The Mating System of the Red Mason Bee, Osmia bicornis (L.) (Hymenoptera : Megachilidae). Journal of Insect Behavior 12: 13-25. DOl: 10.1023/A:1020920929613

Seidelmann K., Ulbrich K., Mielenz N. (2010) Conditional sex allocation in the Red Mason bee, Osmia bicornis. Behavioral Ecology and Sociobiology 64: 337-347. DOI 10.1007/s00265-009-0850-2

Steffan-Dewenter I. (2003) Importance of habitat area and landscape context for species richness of bees and wasps in fragmented orchard meadows. Conservation Biology 17: 1036-1044. DOl: 10.1046/j.1523-1739.2003.01575.x

Strohm E., Daniels H., Warmers C., Stoll C. (2002) Nest provisioning and a possible cost of reproduction in the megachilid bee Osmia bicornis studied by a new observation method. Ethology Ecology Evolution 14: 255-268. DOl: $10.1080 / 08927014.2002 .9522744$

Tepedino V. J., Torchio P. F. (1982) Phenotypic variability in nesting success among Osmia lignaria propinqua females in a glasshouse environment: (Hymenoptera: Megachilidae). Ecological Entomology 7(4): 453-462. DOl: $10.1111 / j .1365-2311.1982$. tb00688.x

Tepedino V. J.; Torchio P. F. (1 989) Influence of Nest Hole Selection on Sex Ratio and Progeny Size in Osmia lignaria propinqua (Hymenoptera: Megachilidae). Annals of the Entomological Society of America 82: 355-360.

Ulbrich K., Seidelmann K. (2001) Modeling population dynamics of solitary bees in relation to habitat quality. Web Ecology 2: 57-64. D0l:10.5194/we-257-2001

Westrich P. (1 989) Die Wildbienen Baden-Württembergs. Ulmer. Stuttgart. 972 pp.

Wilkaniec Z., Giejdasz K., Fliszkiewicz M. (2000) Effect of differentiated nest tubes on their settlement by the solitary bee Osmia bicornis L. (Megachilidae). Pszczelnicze Zeszyty Naukowe 44: 31 1-317. 
Wilkaniec Z., Warakomska Z., Giejdasz K. (2002) Host Woyke J., Jasiński Z. (1973) Influence of external plants of solitary bee Osmia bicornis L. (Apoidea, conditions and the number of spermatozoa enterMegachilidae) defined on the basis of brood cell pol- ing the spermatheca of instrumentally inseminated len analysis. PTPN, Wydz. Nauk Rolniczych i Leśnych, honeybee queens. Journal of Apicultural Research Poland 93: 199-206. 12: 145-151.

Winfree R., Williams N. M., Dushoff J., Kremem C. Wójtowski F. (1971) Bioekologiczne i techniczne (2007) Native bees provide insurance against on- problemy hodowli i praktycznego użytkowania going honey bee losses. Ecology Letters 10: 1 105- pszczół samotnic. Wiadomości Ekologiczne XVII(1): 1113. DOl: 10.1111/j.1461-0248.2007.01110.x 53-58. 